\title{
Wellbeing and urban living: nurtured by nature
}

Lucy Taylor $^{\mathrm{ab}}$, Amy K. Hahs ${ }^{\mathrm{c}}$, Dieter F. Hochuli ${ }^{\mathrm{b}}$

${ }^{a}$ Corresponding author

Email: 1.taylor@sydney.edu.au

Telephone: +61291141957

${ }^{b}$ The School of Life and Environmental Sciences, Faculty of Science, Heydon-Laurence building (A08) The University of Sydney, New South Wales 2006 Australia;

1.taylor@sydney.edu.au; dieter.hochuli@sydney.edu.au;

${ }^{c}$ School of BioSciences, University of Melbourne, Parkville Victoria 3010 Australia;

hahsa@unimelb.edu.au 


\section{Abstract}

In recent decades, empirical evidence has demonstrated that nature can enable urban environments to support human wellbeing. Research into links between nature and human wellbeing is often carried out with one wellbeing index or in single locations, which can limit our understanding of findings. To further this work, we deployed an online survey to residents of the two most-populous cities in both Australia and New Zealand. The survey measured self-reported wellbeing via three indices used widely in the literature: general wellbeing (WHO-5), personal wellbeing, and psychological wellbeing. We compared results with two biodiversity indicators: bird species richness and the Normalised Difference Vegetation Index (NDVI) of respondents' postcodes. We also asked respondents to rate the amount of nature they view from their immediate environment: both at home and at work or other frequent location. Our results support a link between local nature and human wellbeing across all four cities, significantly in the two Australian cities. Qualitative data reveals that urban life can challenge human wellbeing by creating a unique suite of stresses that residents strive to balance. There is the potential for nature to support human wellbeing in typically degraded urban environments. While this work corroborates existing literature demonstrating links between human wellbeing and nature, our qualitative research extends our understanding of these links by providing more detailed and nuanced information.

Keywords: Wellbeing, NDVI, biodiversity, urban, WHO-5

\section{Introduction}

With most of the world's population living in urban areas (WHO 2010), it is critical that urban environments are planned and maintained to promote the wellbeing of residents. There 
are obvious benefits to living in cities, including greater access to health and social services, and opportunities for education (WHO 2010). However urbanisation is also associated with environmental degradation and pollution, over-crowding, increased incidences of both communicative and chronic disease, increased mental and emotional disorders, higher rates of violence, crime and suicide, and there are greater social and financial inequalities among urban populations (WHO 2010). Whether the benefits associated with living in cities outweigh the hazards is yet to be demonstrated (Dye 2008). The proportion of people living in urban areas is projected to increase over time, such that $67 \%$ of the total human population will be living in urban areas by 2050 (United Nations 2012). Opportunities to protect and bolster the wellbeing of urban residents should be pursued.

Links between human wellbeing and nature are well established (for example, Sandifer et al. 2015). To be clear about what we mean by 'nature' and 'wellbeing', which are terms used in multiple contexts across multiple disciplines, definitions of key terms used in this paper are presented in Table 1. Humans exposed to different amounts of nature have demonstrated responses in a number of ways, including physiological (van Den Berg and Custers 2011), emotional (Hartig et al. 2003), and psychological (Dallimer et al. 2012). One of the most common measures of how people experience life in proximity to nature has been through self-reported responses acquired via questionnaire (de Vries et al. 2013). Single case studies that have found links between human wellbeing and nature have focused on discrete locations, single cities (such as Sheffield, UK, in Dallimer et al. 2012), or multiple locations within one country (such as in four Dutch cities in de Vries et al. 2013). However old European cities, for example, are likely to differ ecologically from newer cities in, for instance, New Zealand in terms of the proportion and quality of native habitat and the remaining wildlife. Making international comparisons between cities enables researchers to 
assess how modification of the natural habitat differs in each city and whether that changes how urban residents interact with their environment (Niemelä et al. 2009). There are also advantages to increasing the scale of such research to consider multiple cities, even multiple countries, in order to uncover any patterns that might be culturally specific (Kabisch et al. 2015). How residents interact with nature in cities is affected by social and cultural aspects of societies and this has implications for how their wellbeing is affected (Hartig et al. 2011). Multi-city studies have the potential to inform syntheses that make recommendations that are relevant to multiple populations and to improve understanding about underrepresented areas (Kabisch et al. 2015). Undertaking investigations into the relationships between nature and wellbeing in Oceania is also relevant given that a majority of the literature is situated in the northern hemisphere (Kabisch et al. 2015) and other parts of the world are underinvestigated.

The World Health Organisation definition of health (Table 1) recognises that health is complex; it is more than a physical state, and our physical health interacts with internal (emotional, mental) and external (social) aspects as well. For instance, emotional wellness can also promote resilience against stressors that threaten our mental and physical health (Matheson et al. 2006; Yancura and Aldwin 2008). The WHO definition also recognises that health is more than a lack of illness: it is an active state of wellness. 'Wellbeing' arguably takes this definition further. Wellbeing has emerged as a means to evaluate populations without the problems associated with using the gross domestic product (GDP) to measure nations' living standards (Bates 2009; Krueger and Stone 2014). Wellbeing is often considered synonymous with happiness because it represents an overall satisfaction with one's life (Diener et al. 2003). Supporting the WHO's complex notion of health, subjective assessments of wellbeing have been associated with physical states, such as hormonal or 
immunological responses (Cohen and Hamrick 2003; Smyth et al. 1998), and even mortality (Steptoe et al. 2013). There are numerous self-reported wellbeing indices, each measuring different things depending on the focus of the authors or reporting body, such as, the Organization for Economic Cooperation and Development's (OECD) Better Life Index (OECD 2014). Such indices contribute to understanding about the wellbeing of populations, but it is important to align any research question with the elements that make up the index. That is, the instrument should either be appropriate to the research question, to the populations, or to a combination of both elements.

Our study explored links between nature and human wellbeing across four cities in Australia and New Zealand. The aim was to test whether exposure to nature benefits urban residents' wellbeing in major cities of Oceania. We used three indicators of nature: vegetation, bird species richness, and nature visible from home or work. We measured wellbeing by using three distinct indices to test for differences across cities.

Table 1. Definitions of key terms used in this study

\begin{tabular}{ll}
\hline Term & Definition \\
\hline Health & An overall state of health, including social, mental and physical factors; more than a \\
& lack of disease (WHO 1947) \\
Nature & Nonhuman features and processes including all vegetation and animals, water, air, \\
& geological processes and landscapes (Hartig et al. 2014) \\
Urban & Areas of dense human populations where economic outputs are focussed on industry, \\
& service and technology (instead than farming) (WHO 2010) \\
Wellbeing & How humans evaluate and experience their lives overall (Stone et al. 2014) \\
\hline
\end{tabular}




\section{Method}

We conducted this research in four cities: Auckland and Wellington in New Zealand, and Melbourne and Sydney in Australia. (ABS 2013; Statistics New Zealand 2006). These cities were selected as they are the two most-populous cities of Australia and New Zealand, and they all share a similar climate based on average annual temperatures (minimum and maximum) and precipitation (Peel et al. 2007) (Online Resource 1). Variables used are listed in Table 2. Urban areas were defined by the postcodes included in the geographic information system (GIS) boundaries supplied by the appropriate governmental bodies for the greater urban areas (New Zealand Post and the Australian Bureau of Statistics). These boundaries included greater city areas, including outer suburbs. Respondents were asked to provide their postcode in order to locate them within each city in a non-intrusive manner.

In 2013 , the online survey was made available to the public via a website (www.whoneedsnature.com). Responses took between 10-15 minutes each. The survey was available for six months (November 2013-April 2014), including months from the southern hemisphere's Spring, Summer, and Autumn, to reduce the impact of disorders associated with specific seasons, such as seasonal affective disorder. The website was shared via media releases to Australian and New Zealand organisations, and with local councils in each of the four study cities. Targeted advertising to residents of the four study cities was undertaken via Facebook, and a social media presence was maintained with posts pertaining to urban nature (not the survey per se) for the duration of the survey (i.e., Twitter, Instagram, Facebook). After four months, postcards advertising the study were distributed in public places in each of the study cities (Online Resource 2). 
The 1903 responses were cleaned, with entries from postcodes external to the study cities, dummy postcodes, and test entries removed. The remaining 1819 valid quantitative responses were analysed using a combination of Microsoft Excel and JMP Pro 9.0.0. We used principle components analyses to create wellbeing indices that integrated the questions of three wellbeing instruments, described below, and ran linear regressions with measures of nature. This approach enabled us to treat the wellbeing measures independently and make comparisons between study cities. In all four cities, between $0.011-0.020 \%$ residents of each city responded to the survey (Auckland: 159; Wellington: 85; Melbourne: 700; Sydney: 875).

Ethics approval for the web survey was provided by the University of Sydney Human Research Ethics Committee. Participation was voluntary and responses anonymous. There were two versions of the web survey - one for each country (Australia and New Zealand). The difference between the two surveys reflected different examples of native species where example species were included. In every other respect the two surveys were identical.

Table 2. Variables measured in this study. Biodiversity indicators (avian species richness, NDVI, nature viewed from home and work), three wellbeing indices, and demographics. An open-ended comment was also invited.

\begin{tabular}{llll}
\hline Variable & Scale & Description & Data source \\
\hline Avian species richness & Postcode and & The number of bird species recorded & http://biodiversityma \\
& Urban area & & pping.org - GIS \\
\hline Vegetation & Postcode and & The normalised difference vegetation & NDVI - GIS \\
& Urban area & index (NDVI) & (Landsat scenes \\
& & & downloaded from \\
& & & http://earthexplorer.u \\
\end{tabular}




\begin{tabular}{|c|c|c|c|}
\hline General wellbeing (WHO-5) & Postcode & $\begin{array}{l}\text { 5-item World Health Organization self- } \\
\text { reported wellbeing index (Psychiatric } \\
\text { Research Unit 1998) }\end{array}$ & Survey \\
\hline Personal wellbeing & Postcode & $\begin{array}{l}\text { 10-item personal wellbeing based on } \\
\text { the Personal Wellbeing Index } \\
\text { developed by Cummins et. al (2003) }\end{array}$ & Survey \\
\hline Psychological wellbeing & Postcode & $\begin{array}{l}\text { 7-item psychological wellbeing based } \\
\text { on the reflection axis used in Dallimer } \\
\text { et. al (2012) }\end{array}$ & Survey \\
\hline $\begin{array}{l}\text { How much nature do you see } \\
\text { from your window at home, and } \\
\text { at the place other than your } \\
\text { home where you spend most of } \\
\text { your time (e.g., work) }\end{array}$ & Postcode & $\begin{array}{l}2 \text { items asking respondents to rank how } \\
\text { much nature they can see with five } \\
\text { options (almost all man-made; mostly } \\
\text { man-made; half man-made-half nature; } \\
\text { mostly nature; almost all nature) based } \\
\text { on a study of inner-city children (Faber } \\
\text { Taylor et al. 2002) }\end{array}$ & Survey \\
\hline Demographics & Postcode and & & Survey \\
\hline $\begin{array}{ll}- & \text { Age } \\
\text { - } & \text { Gender }\end{array}$ & Urban area & $\begin{array}{l}\text { - Categorical 10-year groups (18- } \\
76+)\end{array}$ & \\
\hline - Marital status & & - $\quad$ Categorical (female; male) & \\
\hline $\begin{array}{l}\text { - Household composition } \\
\text { (adults, children, pets) }\end{array}$ & & $\begin{array}{l}\text { - Categorical (single; married/de } \\
\text { facto) }\end{array}$ & \\
\hline $\begin{array}{ll}\text { - } & \text { Duration of residence } \\
\text { - } & \text { N. Bedrooms of residence }\end{array}$ & & - Number of resident types & \\
\hline $\begin{array}{ll}\text { - } & \text { Highest level of education } \\
\text { - } & \text { First language }\end{array}$ & & $\begin{array}{ll}- & \text { Number of years } \\
- & \text { Number of bedrooms } \\
- & \text { Categorical (qualification type) } \\
\text { - } & \text { English or open answer }\end{array}$ & \\
\hline $\begin{array}{l}\text { General comment (free text } \\
\text { field) }\end{array}$ & $\begin{array}{l}\text { Individual } \\
\text { responses }\end{array}$ & $\begin{array}{l}\text { "If you have any comments you would } \\
\text { like to make about any aspect of the }\end{array}$ & Survey \\
\hline
\end{tabular}




\section{Wellbeing}

Three common wellbeing indices were used. The WHO-5 (Psychiatric Research Unit 1998) is a five-item, generic questionnaire that can measure the self-reported wellbeing of populations around the world (Topp et al. 2015). It is a useful index given its global usage, clinimetric validity (Topp et al. 2015) and application regardless of disease. While typically used to refer to the previous two weeks, due to the duration of the survey (four months), respondents were asked to consider the previous four weeks when answering. The second index was designed as a national indicator of self-reported personal wellbeing for Australia (Cummins et al. 2003). Personal wellbeing is a measure of life satisfaction comprising seven domains that are averaged together (Cummins et al. 2003). We deemed this index useful because of its local focus and broad use in one of the study countries, Australia. Two questions were omitted from the personal wellbeing index as they were not considered critical to the research question, the optional 'religion/spirituality' and 'personal relationships' questions, but the optional 'general life satisfaction' question was included. The third index we selected is a psychological wellbeing index. It was relevant to include a specific psychological measure in this survey, particularly one that has been used in conjunction with biodiversity in the past (i.e., in Dallimer et al. 2012). Questions were reworded to refer to 'local nature' instead of 'this park', as our survey refers to a respondent's local nature rather than a specific location. We used principal components analysis for each wellbeing item to create indices for general wellbeing (WHO-5), personal wellbeing, and psychological wellbeing (Online Resource 3). We ran linear regressions for each city between wellbeing indices and nature, as measured by NDVI and bird species richness. 


\section{Nature}

We used a combination of human survey and GIS data analysis to measure aspects of nature

(Table 2). Two indicators of nature were used: the amount and vigour of vegetation, and bird species richness. The NDVI and bird richness was calculated for each survey respondent's postcode.

The normalised difference vegetation index (NDVI) measures the presence of vegetation and its photosynthetic vigour (Pereira et al. 2012)and was calculated from Landsat 8 satellite imagery. NDVI has been shown to have a positive relationship with species richness in urban areas, for example, with birds (Bino et al. 2008). The Landsat 8 scenes were taken between June and November 2013 when the survey was commencing, and when scenes could be seen without cloud and during daylight hours. The conversion of digital numbers to top of atmosphere reflectance (USGS 2015) was completed using Exelis VIS ENVI 5.2. We performed the analysis in ArcMap 10.2 to produce the mean and standard deviation NDVI per postcode for all four cities.

We used avian species richness data from biodiversitymapping.org (accessed 10 August 2015), where the authors of previous works (Jenkins et al. 2013; Pimm et al. 2014) make the data publicly available for research. Avian species richness data was obtained from BirdLife International (BirdLife International and NatureServe 2014). Mean species richness and standard deviation were calculated using ArcMap 10.2.

In the online survey, two questions asked respondents how much nature they see from windows in their home, and at the location other than home where they spend the most amount of their time (such as work or university) based on a questionnaire used for inner-city children (Faber Taylor et al. 2002). This subjective measure of nature near home and the second-most regular location of participants was relevant because it reflects participants' 
immediate experience of nature on a daily basis. Furthermore, how people perceive 'naturalness' (van den Berg et al. 2014), biodiversity (Dallimer et al. 2012), and

environmental ‘quality' (Swanson et al. 2015) could have a stronger effect on their wellbeing than ecological descriptors of an environment.

\section{Qualitative responses}

The final survey question (Table 2) was an open question intended to allow respondents to raise any issues or responses that were not explicit throughout the survey.

A total of 386 respondents chose to add a comment at the end of the questionnaire (Auckland: 29; Melbourne: 149; Sydney: 197; Wellington: 11). Qualitative responses to the final question were analysed using QSR NVivo (QSR 2012). Initial coding was performed by one researcher, taking a grounded theory approach to allow unprompted ideas to emerge (Glaser and Strauss 1967). Grounded theory was considered the appropriate methodology given that the question was intentionally general and there were no expectations of the responses. The first researcher identified as many topics that could be identified. A second, more focused coding was performed to confirm which topics overlapped with or were related to other topics. Sets or dimensions of responses were created to reflect the main topics covered by the general comments and were discussed with the second researcher to ensure agreement (as per meetings to discuss emerging interpretations used in Sbaraini et al. 2011).

\section{Survey demographics}

We included the following demographic questions in the survey: age group (18-25, 26-35, $36-45,46-55,56-65,66-75,76+)$, gender, marital status, highest qualification, the composition of households (including adults, children, pets), the number of bedrooms in the 
home, the duration of living in the current home, and respondents' first language. We used a general linear model to look at how different demographic variables influenced general wellbeing (WHO-5), personal wellbeing, and psychological wellbeing indices.

\section{Results}

\section{Wellbeing}

The first principal component for each wellbeing index loaded positively with all questions; the second principal components all explained less than 1 standardized unit of variance (Online Resource 3). General wellbeing (WHO-5) was positively associated with NDVI in Melbourne, Sydney and Wellington, significantly in the Australian cities (Table 3). Personal wellbeing was positively associated with NDVI in all cities, significantly in Melbourne and Sydney. Psychological wellbeing was positively related to NDVI in the Australian cities, particularly in Sydney. Neither general wellbeing nor personal wellbeing were correlated with bird species richness. How much nature respondents said they saw from home or work was positively correlated with all wellbeing indices (Table 3). The most significant results were reported in Auckland, Melbourne and Sydney. Across all four cities, responses to the general wellbeing (WHO-5) and personal wellbeing indices were similar, but the levels of NDVI and bird species richness were significantly different (P < 0.0001; Table 4). Psychological wellbeing also differed significantly among cities $(\mathrm{P}=0.040$; Table 4$)$. 
Table 3. Linear regressions of mean NDVI, bird species richness, and how much nature respondents said they viewed from home or work compared with wellbeing indices. Significant results are bolded.

\begin{tabular}{|c|c|c|c|c|c|c|c|c|c|c|c|c|c|c|c|c|c|c|c|c|}
\hline \multirow[b]{2}{*}{ NDVI Mean } & \multicolumn{7}{|c|}{ Auckland } & \multicolumn{3}{|c|}{ Melbourne } & \multicolumn{7}{|c|}{ Sydney } & \multicolumn{3}{|c|}{ Wellington } \\
\hline & $\beta$ & $\mathrm{F}$ & $\overline{\mathrm{DF}}$ & $\mathrm{P}$ & $\mathrm{R}^{2}$ & $\beta$ & $\mathrm{F}$ & $\overline{\mathrm{DF}}$ & $\mathrm{P}$ & $\mathrm{R}^{2}$ & $\beta$ & $\mathrm{F}$ & DF & $\mathrm{P}$ & $\overline{\mathrm{R}^{2}}$ & $\beta$ & $\mathrm{F}$ & $\overline{\mathrm{DF}}$ & $\mathrm{P}$ & $\mathrm{R}^{2}$ \\
\hline General wellbeing & -1.25 & 1.33 & 1,121 & 0.251 & 0.01 & 1.41 & 6.10 & 1,571 & 0.014 & 0.01 & 2.47 & 14.34 & 1,765 & $<0.001$ & 0.02 & 0.61 & 0.26 & 1,63 & 0.611 & 0.00 \\
\hline Personal wellbeing & 0.47 & 0.21 & 1,120 & 0.649 & 0.00 & 1.43 & 5.30 & 1,568 & 0.022 & 0.01 & 2.62 & 13.36 & 1,757 & $<0.001$ & 0.02 & 0.68 & 0.27 & 1,63 & 0.603 & 0.00 \\
\hline Psychological wellbeing & -0.13 & 0.01 & 1,130 & 0.914 & 0.00 & 0.90 & 1.96 & 1,597 & 0.162 & 0.00 & 2.29 & 11.42 & 1,796 & 0.001 & 0.01 & -2.68 & 3.87 & 1,67 & 0.053 & 0.05 \\
\hline Bird species richness & $\beta$ & $\mathrm{F}$ & $\mathrm{DF}$ & $\mathrm{P}$ & $\mathrm{R}^{2}$ & $\beta$ & $\mathrm{F}$ & $\mathrm{DF}$ & $\mathrm{P}$ & $\mathrm{R}^{2}$ & $\beta$ & $\mathrm{F}$ & $\mathrm{DF}$ & $\mathrm{P}$ & $\mathrm{R}^{2}$ & $\beta$ & $\mathrm{F}$ & $\mathrm{DF}$ & $\mathrm{P}$ & $\mathrm{R}^{2}$ \\
\hline General wellbeing & 0.00 & 0.18 & 1,121 & 0.671 & 0.00 & -0.00 & 0.02 & 1,563 & 0.886 & 0.00 & -0.00 & 0.47 & 1,751 & 0.494 & 0.00 & -0.01 & 0.85 & 1,63 & 0.359 & 0.01 \\
\hline Personal wellbeing & 0.00 & 0.56 & 1,120 & 0.457 & 0.00 & -0.01 & 1.37 & 1,560 & 0.242 & 0.00 & -0.00 & 0.08 & 1,746 & 0.780 & 0.00 & 0.01 & 0.13 & 1,63 & 0.723 & 0.00 \\
\hline Psychological wellbeing & 0.00 & 0.93 & 1,130 & 0.337 & 0.01 & 0.01 & 4.70 & 1,587 & 0.031 & 0.01 & 0.00 & 0.00 & 1,782 & 0.961 & 0.00 & 0.03 & 2.47 & 1,67 & 0.121 & 0.04 \\
\hline How much nature at home & $\beta$ & $\mathrm{F}$ & $\overline{\mathrm{DF}}$ & $\mathrm{P}$ & $\mathrm{R}^{2}$ & $\beta$ & $\mathrm{F}$ & $\overline{\mathrm{DF}}$ & $\mathrm{P}$ & $\mathrm{R}^{2}$ & $\beta$ & $\mathrm{F}$ & $\overline{\mathrm{DF}}$ & $\mathrm{P}$ & $\mathrm{R}^{2}$ & $\beta$ & $\mathrm{F}$ & $\overline{\mathrm{DF}}$ & $\mathrm{P}$ & $\mathrm{R}^{2}$ \\
\hline General wellbeing & -0.02 & 0.61 & 4,112 & 0.655 & 0.02 & 0.25 & 3.14 & 4,548 & 0.014 & 0.02 & 0.34 & 6.45 & 4,727 & $<0.001$ & 0.03 & 0.02 & 0.49 & 4,56 & 0.744 & 0.03 \\
\hline Personal wellbeing & 0.46 & 2.20 & 4,111 & 0.074 & 0.07 & 0.24 & 2.97 & 4,544 & 0.977 & 0.00 & 0.46 & 10.29 & 4,720 & $<0.001$ & 0.05 & 0.49 & 1.58 & 4,56 & 0.193 & 0.10 \\
\hline Psychological wellbeing & 0.69 & 3.18 & 4,121 & 0.016 & 0.10 & 0.03 & 0.12 & 4,573 & 0.019 & 0.02 & 0.15 & 2.05 & 4,753 & 0.085 & 0.01 & 0.02 & 1.34 & 4,60 & 0.264 & 0.08 \\
\hline How much nature at work & $\beta$ & $\mathrm{F}$ & $\overline{\mathrm{DF}}$ & $\mathrm{P}$ & $\mathrm{R}^{2}$ & $\beta$ & $\mathrm{F}$ & DF & $\mathrm{P}$ & $\mathrm{R}^{2}$ & $\beta$ & $\mathrm{F}$ & DF & $\mathrm{P}$ & $\mathrm{R}^{2}$ & $\beta$ & $\mathrm{F}$ & $\overline{\mathrm{DF}}$ & $\mathrm{P}$ & $\overline{\mathrm{R}^{2}}$ \\
\hline General wellbeing & 0.65 & 3.26 & 4,100 & 0.015 & 0.12 & 0.24 & 2.81 & 4,515 & 0.025 & 0.02 & 0.18 & 2.73 & 4,674 & 0.028 & 0.02 & 0.05 & 1.55 & 4,53 & 0.202 & 0.10 \\
\hline Personal wellbeing & 0.62 & 3.89 & 4,99 & 0.006 & 0.14 & 0.04 & 0.46 & 4,512 & 0.765 & 0.00 & 0.22 & 3.03 & 4,666 & 0.017 & 0.02 & 0.09 & 0.61 & 4,53 & 0.659 & 0.04 \\
\hline Psychological wellbeing & -0.01 & 0.63 & 4,108 & 0.643 & 0.02 & 0.08 & 0.54 & 4,540 & 0.704 & 0.00 & 0.14 & 1.32 & 4,703 & 0.260 & 0.01 & 0.22 & 0.51 & 4,56 & 0.728 & 0.04 \\
\hline
\end{tabular}


Table 4. Responses to the general wellbeing (WHO-5) and personal wellbeing indices were similar across all four study cities. There were differences in how Psychological wellbeing, NDVI and Bird species richness were reported. Bolded figures are significant.

\begin{tabular}{lrrc}
\hline Variable & ChiSquare & DF & P \\
\hline WHO-5 & 3.63 & 3 & 0.304 \\
Personal wellbeing & 7.19 & 3 & 0.066 \\
Psychological wellbeing & 8.31 & 3 & $\mathbf{0 . 0 4 0}$ \\
NDVI (postcode) & 50.08 & 3 & $<\mathbf{0 . 0 0 1}$ \\
Bird species richness (postcode) & 1357.55 & 3 & $<\mathbf{0 . 0 0 1}$ \\
\hline
\end{tabular}

\section{Nature}

The interquartile variation across cities demonstrates a range of vegetation and bird species present (Figure 1). There were more bird species in Australian cities than in the New Zealand cities. Respondents who reported having greater nature at home were significantly more likely to live in a postcode with higher NDVI (Table 5). Respondents with at least some nature at home were situated in postcodes with higher bird species diversity (Table 5). There was a significant relationship between NDVI and bird species richness. 


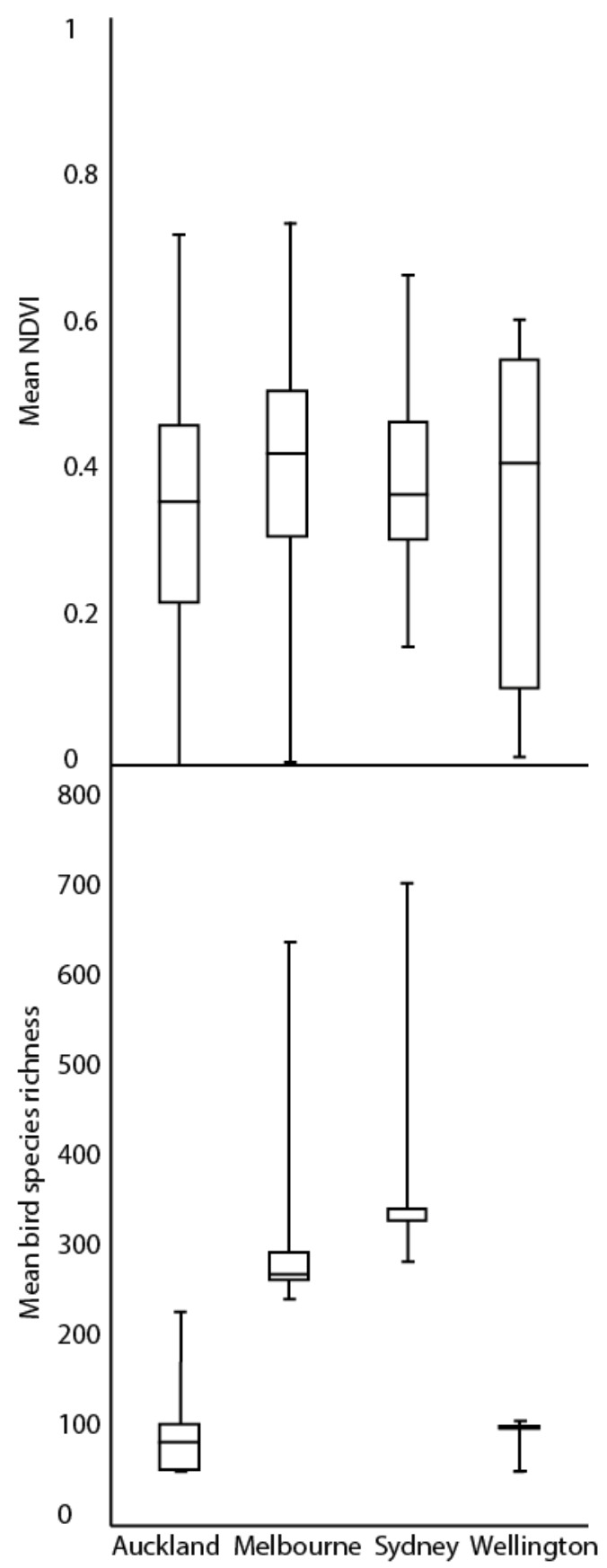

Figure 1. The NDVI and bird species richness varied across the four study cities. Whiskers show the minimum and maximum ranges, and boxes show the interquartile ranges within respondents' postcodes, either side of the median. 
Table 5. Linear regressions of the NDVI and bird species richness per postcode compared with other variables. Significant relationships are bolded.

\begin{tabular}{lccccccccc} 
& \multicolumn{2}{l}{ Auckland } & \multicolumn{2}{l}{ Melbourne } & \multicolumn{2}{l}{ Sydney } & \multicolumn{2}{l}{ Wellington } \\
\hline NDVI Mean & $\mathrm{P}$ & $\mathrm{R}^{2}$ & $\mathrm{P}$ & $\mathrm{R}^{2}$ & $\mathrm{P}$ & $\mathrm{R}^{2}$ & $\mathrm{P}$ & $\mathrm{R}^{2}$ \\
\hline How much nature at home? & 0.141 & 0.05 & $<\mathbf{0 . 0 0 1}$ & 0.26 & $<\mathbf{0 . 0 0 1}$ & 0.24 & 0.083 & 0.11 \\
How much nature at work (or similar)? & 0.566 & 0.02 & $\mathbf{0 . 0 1 5}$ & 0.02 & $\mathbf{0 . 0 1 4}$ & 0.02 & 0.142 & 0.10 \\
General wellbeing & 0.251 & 0.01 & $\mathbf{0 . 0 1 4}$ & 0.01 & $\mathbf{0 . 0 0 0}$ & 0.02 & 0.611 & 0.00 \\
Personal wellbeing & 0.460 & 0.00 & $\mathbf{0 . 0 2 8}$ & 0.01 & $\mathbf{0 . 0 0 1}$ & 0.02 & 0.588 & 0.00 \\
Psychological wellbeing & 0.913 & 9.07 & 0.179 & 0.00 & $<\mathbf{0 . 0 0 1}$ & 0.01 & 0.053 & 0.05 \\
Bird richness of postcodes (mean) & 0.074 & 0.02 & $<\mathbf{0 . 0 0 1}$ & 0.19 & $<\mathbf{0 . 0 0 1}$ & 0.13 & $<\mathbf{0 . 0 0 1}$ & 0.14 \\
\hline Bird richness & $\mathrm{P}$ & $\mathrm{R}^{2}$ & $\mathrm{P}$ & $\mathrm{R}$ & $\mathrm{P}$ & $\mathrm{R}^{2}$ & $\mathrm{P}$ & $\mathrm{R}^{2}$ \\
\hline How much nature at home? & 0.363 & 0.03 & $<\mathbf{0 . 0 0 1}$ & 0.06 & $<\mathbf{0 . 0 0 1}$ & 0.07 & 0.930 & 0.01 \\
How much nature at work (or similar)? & 0.557 & 0.02 & 0.787 & 0.00 & 0.677 & 0.03 & $\mathbf{0 . 0 4 4}$ & 0.14 \\
\hline
\end{tabular}

\section{Qualitative responses}

Although comments were coded separately for each city, themes were coherent across all locations. Focussed coding revealed four sets or dimensions of comments: those concerning the survey itself, nature, wellbeing, and urban life. For instance, the following comment, also discussed above, is included in all three dimensions (nature, wellbeing and urban life): “There is a park near where I live. It is great to have but it is right on the train line... I do not always feel rested and calm. When I go to nature without hearing trains I feel calm and peaceful." This is because the comment initially fits into the nature dimension: parks and nature are mentioned; the sense of feeling calm, peaceful and rested (or not) fits with the wellbeing dimension; and the juxtaposition of these themes with themes about transport and noise also fit into the urban life dimension. Themes can be relevant to more than one dimension, for example, the vegetation theme might be relevant to both the nature and the wellbeing; for example, "I think the quantity of nature and trees has a direct effect on happiness" applies to both nature and wellbeing dimensions. 
More than half of those who commented $(n=200)$ made at least part of their comment about the survey itself. This included positive responses to the survey, suggestions, or complaints. Seven respondents' comments indicate that their awareness of local nature would be heightened after completing the survey; "I live in a unit but enjoy the nature around my area. This survey has made me think more about appreciating it even more." Some respondents $(n=10)$ noted that they were new to the area in which they live, such as, "Not Australian, from the UK, so don't have much knowledge in native animals and birds."

\section{Wellbeing dimension}

The wellbeing dimension includes comments concerning themes listed in Table 6. Some respondents made it clear that nature did not cause their unhappiness or negative state, such as "sometimes I think the reason I don't feel calm or am able to ponder life in a park is because I need to watch my 2 year old". Some respondents felt nature supported their wellbeing or recovery from a difficult time, for example, "I have long-term depression which I am being treated for. Going to the local bush and pulling up weeds one morning per week is a great help to me". In general, wellbeing is complex and multiple factors are involved. Nevertheless, nature provides some support to most respondents who left comments relating to wellbeing.

Table 6. Example comments demonstrate the range of themes that formed a dimension about wellbeing.

\begin{tabular}{ll}
\hline Theme & Example comment \\
\hline Children/family & "I have a very young baby \& a toddler so I think my health/emotional state is more linked \\
& to that than nature in [the] area!" - Melbourne respondent \\
"Being able to walk my dog down at the beach, or go up in to the hills is a great stress \\
Exercise \\
relief and keeps me fit and healthy and best of all it's free." - Wellington respondent \\
"I hope this raises awareness of the value of green space to personal wellbeing. I love my \\
garden and the birds and insects it gives shelter to, and I need public parks in which to
\end{tabular}


exercise my two dogs." - Melbourne respondent

Vegetation

Wildlife

Rejuvenation

Safety

More detail about life

situation

Happiness and wellbeing

"Having a small vegetable garden and flowers in pots makes me feel happy and content.... It is wonderful to see things grow in the city." - Sydney respondent

"I couldn't bear to live without green spaces. Living where I do I am incredibly lucky to have access to wetlands, rivers and woodland with a huge diversity of plants and animals. I can live without highways but I can't live without nature." - Sydney respondent

"I need to be around natural light, fresh air, flora \& fauna as it impacts how I think, feel \& act. I feel more free \& restored around nature." Sydney respondent

"[I] love native secluded bush walks in city but concern over safety, when alone, trumps this." - Auckland respondent

"I have had a broken leg the past month - so this may affect results focusing on health and wellbeing." - Melbourne respondent

"I suffer from anxiety and depression. I keep a garden on my balcony which I find helps my mental and physical health." - Sydney respondent

\section{Nature dimension}

Themes in the nature dimension are demonstrated in Table 7. The nature dimension described respondents' reactions to non-human animals and plants, including topics of concern (such as degradation of wilderness areas), experiences of nature, and thoughts or recommendations about how people should preserve or interact with nature. No single natural profile was preferred, but comments suggested that a variety of nature is valued by respondents: "I felt a bit manipulated when I had to choose between fountains and natural water systems - both are good!” There was a perceptible thread of comments that reflected an awareness of colonialism and differences in culture (n.11) where respondents analysed their preferences of nature, such as, "My preference is for introduced plants and trees as I have European roots."

Table 7. Example comments demonstrate the range of themes that formed a dimension about nature.

Theme Example comment




\begin{tabular}{|c|c|}
\hline Conservation & $\begin{array}{l}\text { "I strongly believe that we need to put in more effort to educate the public on the importance of } \\
\text { their actions towards nature. ...I hope that we can preserve nature as it is and not degrade it } \\
\text { further." - Melbourne respondent }\end{array}$ \\
\hline Custodianship & $\begin{array}{l}\text { "Glad to do what I can to help nature, after all God placed us here and positioned us as } \\
\text { custodians of the planet." - Sydney respondent }\end{array}$ \\
\hline Culture & $\begin{array}{l}\text { "We don't actually feed birds - we provide water. The vegetation question is a tricky one: I love } \\
\text { natural bush, but enjoy exotic gardens and parks aesthetically. The colonial's dilemma." - } \\
\text { Sydney respondent }\end{array}$ \\
\hline National parks & $\begin{array}{l}\text { "I feel more rejuvenated by visiting a national park with incredible vistas and natural } \\
\text { landscapes." - Sydney respondent }\end{array}$ \\
\hline Urban parks & $\begin{array}{l}\text { "There are not many inner city places where you can feel a sense of nature untamed. Most parks } \\
\text { are manicured and resemble little of the Australian bush." - Melbourne respondent }\end{array}$ \\
\hline $\begin{array}{l}\text { Native animals and } \\
\text { plants }\end{array}$ & $\begin{array}{l}\text { "I love native plants and animals and believe they are important for a city for OUR sake, but I } \\
\text { do feel that a city is an unsafe environment for most native animals." - Sydney respondent }\end{array}$ \\
\hline $\begin{array}{l}\text { Weeds or pest } \\
\text { animals and plants }\end{array}$ & $\begin{array}{l}\text { "We have feral cats breeding... I don't feel at ease or relaxed in the parks nearby due to the } \\
\text { lack of foresight and planning and the amount of trash and weeds everywhere" - Sydney } \\
\text { respondent }\end{array}$ \\
\hline Pets & $\begin{array}{l}\text { "There should be more open spaces around where I live and more off the leash parks so we can } \\
\text { take our dogs and to allow them to run around." - Sydney respondent }\end{array}$ \\
\hline Wildlife & $\begin{array}{l}\text { "We usually see lots of spiders and lizards/ cicadas in our yard/house but have not noticed any } \\
\text { lately. Lorikeet flock has diminished." - Sydney respondent }\end{array}$ \\
\hline Vegetation & $\begin{array}{l}\text { "I do think growing population means sacrificing nature for our needs, but I hope we bring } \\
\text { plants, herbs and our kind of vegetation closer to home - even rooftops could provide new types } \\
\text { of garden." - Auckland respondent }\end{array}$ \\
\hline
\end{tabular}

\section{Urban life}

The urban life dimension was not anticipated as it was not part of the survey questionnaire. However, respondents were asked to complete the survey if they lived in an urban area and any postcodes that fell outside the urban boundaries were excluded. Example comments from themes that feature in the urban life dimension are included in Table 8. The management and governance of urban spaces was 
relevant, but respondents also recognised that their personal situations affected their interaction with nature. For example, the following comment reflected economic struggle, initiatives such as growing food at home, being responsible for pets and managing stress: "Any dissatisfaction is due to current financial climate and the struggle to pay bills, buy food etc. I'm growing as much as I can and swapping home grown food with friends where I can. Being able to walk my dog down at the beach, or go up in to the hills is a great stress relief and keeps me fit and healthy and best of all it's free" (Wellington participant). Variants of this kind of comment revealed that urban life is stressful, can involve trade-offs in values, and can require a balancing act to maintain.

Table 8. Example comments demonstrate the range of themes that formed a dimension about urban life.

\section{Theme Example comment}

Urban life as a balancing "I am not completely satisfied in terms of where I live, since if I had the choice, I would act choose to live outside of the city in a more rural location surrounded by nature, but I can't move because of the kind of work I do. But, overall I feel lucky to live near the beach (nature) and so I am content. We pay more than we can afford to live as close to nature as possible in the city." - Sydney respondent

Culture "If activities can be integrated with natural elements, it's even better... The mix of natural and cultural landscapes is exactly what makes my area so nice to live in." Sydney respondent

Development

Dissatisfaction

Government
"East/West link is having a MAJOR downer on my emotional state. Royal Park being destroyed is the WORST thing in my world at the moment." - Melbourne respondent "I have 2 young kids under 6 yrs and my husband is working really hard in achieving our financial goals. I feel that other than being a full-time mum and house wife, I am not fulfilling my potentials for the purpose of my life."

"Without natural areas, gardens and trees, human life would be bereft. It is wicked that councils and governments are gradually usurping these areas that belong to everyone." Sydney respondent 
Rejuvenation

Safety

Transport

More detail about life situation
"I would be really disappointed if the Westconnex freeway was approved and took away the wonderful green/bush reserve at Tempe Reserve. It is a haven for native life, and peaceful respite from the fast paced inner city." - Sydney respondent

"Re: walking around etc, [there are] no options to discuss personal safety issues." Sydney respondent

"In the last 4 weeks I have given up a job that has been very stressful/toxic to my mental health, since I have been outdoors a lot and enjoyed getting closer to nature again with my areas for walking, it is truly a blessing to have these spaces, only a shame I need to drive." - Auckland respondent

“I struggle with anxiety so though I love nature it doesn't really help me with my anxiety unfortunately it comes with me no matter where I am. I guess it's worse in a noisy shopping mall though than on a bush walk." - Melbourne respondent

\section{Survey Demographics}

In a comparison with census data, the survey respondents were not representative of the population. The most significant difference concerned the highest level of education. The proportion of respondents with a postgraduate qualification (25-32\%) was fivefold the proportion of the population with a postgraduate qualification (4-6\%) (ABS 2011; Statistics New Zealand 2013). Females and participants who are married or in a de facto partnership were over-represented, and participants over 75 years of age were underrepresented in the survey (ABS 2011; Statistics New Zealand 2013). Most of the survey participants' households (22\% over all four cities) comprised 2 adults and no children or pets.

A summary of fit of demographic elements of the three wellbeing indices (Online Resource 4) indicate some influence on responses. Gender and marital status affect personal wellbeing, with married respondents and women having higher personal wellbeing. Respondents in their late 40s and early 50s had higher personal wellbeing and general wellbeing (WHO-5) than other age groups. The 
level of education had a positive effect on personal wellbeing. There were no significant interactions between relevant demographic measures and nature for all comparisons (Online Resource 5).

\section{Discussion}

Overall, our study suggested that nature in proximity to where people spend most of their time (for example, at home or work) and vegetation in their postcode are associated with respondents' wellbeing. Three wellbeing indices were used, but the strongest relationships with the wellbeing indices occurred in the Australian cities.

There were no significant associations between any of the measures of nature and wellbeing in Wellington. While it has been argued that there is low spatial variation between natural and nonnatural spaces in New Zealand cities and that is a possible reason for New Zealand residents' wellbeing being less affected by nature exposure (Richardson et al. 2010), our GIS analysis demonstrates that the greatest variation in this study in vegetation occurs in Wellington (Figure 1). We suggest that the weaker patterns in the New Zealand cities is an artefact of the lower response rates in the New Zealand cities. This could be related to the smaller population of the New Zealand cities, particularly Wellington, when compared with the other cities in our study. However, that the number of respondents from each city represented a similar percentage of the total population of that city (between $0.01-0.02 \%$ of each city's population). Another possible explanation for the lower response rate in the New Zealand could be associated with Auckland and Wellington having fewer local councils than the Australian cities, thus reducing the possible publicization of our survey to those council's constituents.

While there were significant predictive relationships between some nature indicators and wellbeing, the $\mathrm{R}_{2}$ values for these relationships were low. This indicates a need to tease out the reasons for the variation. Responses to the open question provided some detail that illustrated the nature of 
respondents' reactions to nature in their cities and how they thought it affected their wellbeing. The qualitative comments of respondents from all four cities supported the significant quantitative findings of Melbourne and Sydney in relation to wellbeing. This could support that the weaker patterns in the New Zealand cities is associated with the lower response rate, rather than a different association between nature and wellbeing. Further research, particularly qualitative research, will explore the variation in patterns found between nature and wellbeing in the study cities.

Stress is a threat to the wellbeing of urban dwellers (Taylor and Hochuli 2015). While cities have benefits, such as the culture and energy of high density populations, stresses can have multiple effects on multiple aspects of our health (Dye 2008). Urban stress might include physical stressors such as pollution, noise, social stressors due to high density living, economic stressors, and the unrelenting stress of trying to balance work, family and personal lives (Sathyanarayana Rao and Indla 2010). These sorts of stresses were evident in the urban life dimension of the qualitative responses to the survey. Our findings are supported by a recent study that demonstrated via functional MRI scans that urban residents use a different part of their brains to process stress when compared with rural residents: the amygdala region of the brain, which is associated with fear and anxiety (Lederbogen et al. 2011). The dimensions of qualitative responses concerning wellbeing and nature were unsurprising because that was the focus of the survey. However, the dimension concerning urban life was unexpected because there was not a dedicated suite of questions on urban life that would have prompted thought in that regard. Of course, wellbeing and stress are inextricable, however the urban life dimension differed from wellbeing in that it involved being able to manage, prioritise, cope with, juggle or balance various aspects of urban life. The extra stress associated with urban areas and the stress caused by the balancing act respondents described in our study is what makes the urban life so challenging. We suggest that further investigation of urban stress and its mitigation is worth pursuing. 
The urban life dimension suggested that respondents found some support when they encountered or sought out nature to help them cope with urban stresses. Nature represented a "peaceful respite from the fast-paced inner city" and "a great stress relief" and helped people "maintain balance". Such comments support two areas of the greenspace and wellbeing literature in a way that the quantitative analysis was unable to: Attention Restoration Theory (Kaplan 1995), and stress recovery (Ulrich et al. 1991). Attention Restoration Theory posits that the multiple stimuli associated with urban environments can overwhelm us, whereas natural environments that conform to certain criteria can restore our cognitive capacity. Stress recovery and positive moods resulted more quickly and completely when participants were exposed to natural environments rather than urban environments (Ulrich et al. 1991). A number of studies have built on these findings when people look at or spend time in nature, for example, participants experience lower blood pressure and improved mood (such as Hartig et al. 2003), and nature sounds facilitate participants' stress recovery (Alvarsson et al. 2010). While a number of respondents in our study recognised that they receive benefits when they spend time in nature, other studies suggest that an awareness of possible benefits is often underestimated (Nisbet and Zelenski 2011).

Wellbeing differs among nations (Diener et al. 2003) but the results of this survey suggest that in Australia and New Zealand, residents' perceptions of their lives are not so different. General and personal wellbeing were similar across all four cities (Table 4). Both countries are similarly wealthy, and share very similar governance arrangements, development histories and cultural similarities. The wealth of the country, with its implications for longevity, human rights and equality, has been shown to impact wellbeing (Diener et al. 2003). Subjective Wellbeing Homeostasis theory suggests that severe variation of wellbeing is unlikely across similarly-developed nations (Cummins et al. 2003). While significant differences between general and personal wellbeing were not detected by the coarse measures we used, there is evidence that local nature is important. The differences in psychological wellbeing across cities support this (Table 4). 
The lack of a consistent relationship between bird species richness and NDVI was unexpected, given previous studies (Bino et al. 2008). An explanation could be the coastal position of all study cities and inclusion of seabirds in the data; seabirds would interact less with terrestrial vegetation measured by NDVI. It could be that other measures should be considered, such as the amount and type of vegetation in a city rather than its vigour (e.g., Ikin et al. 2013). The bird species data have been published for use for research, such as identifying priority conservation areas (Jenkins et al. 2013) and to present the known distribution of identified species (Pimm et al. 2014). As more species richness data become more available (such as those at www.biodiversitymapping.org), we expect it to be worthwhile to repeat cross-country, multi-city studies such as this. This study potentially demonstrates that global ecological information is under developed (McDonnell et al. 2009), and highlights the need for further urban ecology work.

Due to the public and voluntary nature of the survey, respondents self-selected. This may have influenced the study results by portraying the perspectives of an unrepresentative demographic sample. Further research to seek input from under-represented groups, such as those without postgraduate qualifications and families, would complement the data presented in this study.

\section{Conclusions}

Wellbeing is supported by nature that is located in close proximity to where people spend their time (e.g., at home or at work) and within residents' postcodes. Residents from the two most populous cities of Australia and New Zealand responded in a consistent manner for general wellbeing (WHO5) and personal wellbeing indices, suggesting similarities in general wellbeing across all four cities. Qualitative responses suggest that urban life presents a unique suite of stressors to residents. While the presence of nature in cities can support restoration from stress, further qualitative research would 
provide detail about how respondents value nature and whether the frequency of their interactions

with nature has an impact on their wellbeing.

There were differences in how the NDVI and bird species richness were distributed across the four cities, and differences in how psychological wellbeing was reported. How the differences in nature distribution affects psychological wellbeing in cities would be a useful topic for further research.

Nature is not the sole solution to urban stress, but our study suggests that is an important part of the balance that urban residents strive to keep.

\section{References}

ABS (2011) 2011 Census QuickStats. http://www.abs.gov.au/websitedbs/censushome.nsf/home/data. Accessed 23 January 2016

ABS (2013) 3218.0 - Regional Population Growth, Australia, 2011-12. http://www.abs.gov.au/ausstats/abs@.nsf/latestProducts/3218.0Media\%20Release12011-12. Accessed 25 May 2013

Alvarsson JJ, Wiens S, Nilsson ME (2010) Stress Recovery during Exposure to Nature Sound and Environmental Noise International Journal of Environmental Research and Public Health

Bates W (2009) Gross national happiness Asian-Pacific Economic Literature 23:1-1 doi:10.1111/j.14678411.2009.01235.x

Bino G, Levin N, Darawshi S, Van Der Hal N, Reich-Solomon A, Kark S (2008) Accurate prediction of bird species richness patterns in an urban environment using Landsat-derived NDVI and spectral unmixing International Journal of Remote Sensing 29:3675-3700 doi:10.1080/01431160701772534

BirdLife International and NatureServe (2014) Bird Species Distribution Maps of the World

Cohen S, Hamrick N (2003) Stable individual differences in physiological response to stressors: implications for stress-elicited changes in immune related health vol 17. Elsevier Inc, San Diego. doi:10.1016/S0889-1591(03)00110-7

Cummins RA, Eckersley R, Pallant J, Van Vugt J, Misajon R (2003) Developing a National Index of Subjective Wellbeing: The Australian Unity Wellbeing Index Social Indicators Research 64:159-190 doi:10.1023/A:1024704320683

Dallimer M et al. (2012) Biodiversity and the Feel-Good Factor: Understanding Associations between SelfReported Human Well-being and Species Richness BioScience 62:47-55 doi:10.1525/bio.2012.62.1.9

de Vries S, van Dillen SME, Groenewegen PP, Spreeuwenberg P (2013) Streetscape greenery and health: Stress, social cohesion and physical activity as mediators Social Science \& Medicine 94:26-33 doi:10.1016/j.socscimed.2013.06.030

Diener E, Oishi S, Lucas RE (2003) Personality, Culture, and Subjective Well-being: Emotional and Cognitive Evaluations of Life Annual Review of Psychology 54:403-425 doi:10.1146/annurev.psych.54.101601.145056

Dye C (2008) Health and Urban Living Science 319:766-769 doi:10.1126/science.1150198

Faber Taylor A, Kuo FE, Sullivan WC (2002) Views of nature and self-discipline: Evidence from inner-city children Journal of Environmental Psychology 22:49-63 doi:10.1006/jevp.2001.0241

Glaser BG, Strauss AL (1967) The Discovery of Grounded Theory; Strategies for Qualitative Research. Aldine Transaction, Piscataway, New Jersey. doi:10.1097/00006199-196807000-00014

Hartig T, Evans GW, Jamner LD, Davis DS, Gärling T (2003) Tracking restoration in natural and urban field settings Journal of Environmental Psychology 23:109-123 doi:10.1016/\$0272-4944(02)00109-3 
Hartig T, Mitchell R, de Vries S, Frumkin H (2014) Nature and health Annual review of public health:207 doi:10.1146/annurev-publhealth-032013-182443

Hartig T et al. (2011) Health Benefits of Nature Experience: Psychological, Social and Cultural Processes. In: Nilsson K (ed) Forests, trees and human health. vol Book, Whole. Springer, New York,

Ikin K, Beaty RM, Lindenmayer DB, Knight E, Fischer J, Manning AD (2013) Pocket parks in a compact city: how do birds respond to increasing residential density? Landscape Ecology 28:45-56 doi:10.1007/s10980-012-9811-7

Jenkins CN, Pimm SL, Joppa LN (2013) Global patterns of terrestrial vertebrate diversity and conservation Proceedings of the National Academy of Sciences 110:E2602-E2610 doi:10.1073/pnas.1302251110

Kabisch N, Qureshi S, Haase D (2015) Human-environment interactions in urban green spaces - A systematic review of contemporary issues and prospects for future research Environmental Impact Assessment Review 50:25-34 doi:10.1016/j.eiar.2014.08.007

Kaplan S (1995) The restorative benefits of nature: Toward an integrative framework Journal of Environmental Psychology 15:169-182 doi:10.1016/0272-4944(95)90001-2

Krueger AB, Stone AA (2014) Progress in measuring subjective well-being Science 346:42-43

Lederbogen $F$ et al. (2011) City living and urban upbringing affect neural social stress processing in humans Nature 474:498-501 doi:10.1038/nature10190

Matheson FI, Moineddin R, Dunn JR, Creatore MI, Gozdyra P, Glazier RH (2006) Urban neighborhoods, chronic stress, gender and depression Social science \& medicine (1982) 63:2604-2616 doi:10.1016/j.socscimed.2006.07.001

McDonnell MJ, Breuste JH, Hahs AK (2009) Introduction. In: McDonnell MJ, Breuste JH, Hahs AK (eds) Ecology of cities and towns: a comparative approach. Cambridge University Press, Cambridge,

Niemelä J, Kotze DJ, Yli-Pelkonen V (2009) Comparative urban ecology: challenges and possibilities. In: McDonnell MJ, Hahs AK, Breuste JH (eds) Ecology of cities and towns. Cambridge, Cambridge University Press,

Nisbet EK, Zelenski JM (2011) Underestimating Nearby Nature: Affective Forecasting Errors Obscure the Happy Path to Sustainability Psychological Science 22:1101-1106 doi:10.1177/0956797611418527

OECD OfECaD (2014) Better life index: executive summary. OECD Publishing. http://www.oecdbetterlifeindex.org/about/better-life-initiative. Accessed 23 May 2016

Peel MC, Finlayson BL, McMahon TA (2007) Updated world map of the Koppen-Geiger climate classification Hydrol Earth System Science 11:1633-1644

Pereira G, Foster S, Martin K, Christian H, Boruff BJ, Knuiman M, Giles-Corti B (2012) The association between neighborhood greenness and cardiovascular disease: An observational study BMC Public Health 12:466-466 doi:10.1186/1471-2458-12-466

Pimm SL et al. (2014) The biodiversity of species and their rates of extinction, distribution, and protection SCIENCE 344:987-987 doi:10.1126/science.1246752

Psychiatric Research Unit (1998) The WHO-5 Website. Mental Health Centre North Zealand. https://www.psykiatri-regionh.dk/who-5/.

QSR (2012) NVivo qualitative data analysis Software vol 11. QSR International Pty Ltd.,

Richardson E, Pearce J, Mitchell R, Day P, Kingham S (2010) The association between green space and causespecific mortality in urban New Zealand: an ecological analysis of green space utility BMC public health 10:240-240 doi:10.1186/1471-2458-10-240

Sandifer PA, Sutton-Grier AE, Ward BP (2015) Exploring connections among nature, biodiversity, ecosystem services, and human health and well-being: Opportunities to enhance health and biodiversity conservation ECOSYSTEM SERVICES 12:1-15 doi:10.1016/j.ecoser.2014.12.007

Sathyanarayana Rao TS, Indla V (2010) Work, family or personal life: Why not all three Indian Journal of Psychiatry 52:295-297 doi:10.4103/0019-5545.74301

Sbaraini A, Carter SM, Evans RW, Blinkhorn A (2011) How to do a grounded theory study: a worked example of a study of dental practices

Smyth J, Ockenfels MC, Porter L, Kirschbaum C, Hellhammer DH, Stone AA (1998) Stressors and mood measured on a momentary basis are associated with salivary cortisol secretion Psychoneuroendocrinology 23:353-370 doi:10.1016/\$0306-4530(98)00008-0 
Statistics New Zealand (2006) 2006 Census. http://www.stats.govt.nz/Census/2006CensusHomePage. Accessed 25 May 2013

Statistics New Zealand (2013) 2013 Census. http://stats.govt.nz/Census/2013-census/. Accessed 23 January 2016

Steptoe A, Shankar A, Demakakos P, Wardle J (2013) Social isolation, loneliness, and all-cause mortality in older men and women PNAS 110:5797-5801

Stone AA, Mackie C, Framework PMSWBPR, Statistics CN, Education DBSS, Council NR (2014) Subjective Well-Being: Measuring Happiness, Suffering, and Other Dimensions of Experience. National Academies Press,

Swanson V, Sharpe T, Porteous C, Hunter C, Shearer D (2015) Well-Being in Urban Residents in Scotland Ecopsychology 8:121-130

Taylor L, Hochuli DF (2015) Creating better cities: how biodiversity and ecosystem functioning enhance urban residents' wellbeing Urban Ecosystems 18:747-762 doi:10.1007/s11252-014-0427-3

Topp CW, Østergaard SD, Søndergaard S, Bech P (2015) The WHO-5 Well-Being Index: A Systematic Review of the Literature Psychotherapy and psychosomatics 2015:167-176

Ulrich RS, Simons RF, Losito BD, Fiorito E, Miles MA, Zelson M (1991) Stress recovery during exposure to natural and urban environments Journal of Environmental Psychology 11:201-230 doi:10.1016/s0272-4944(05)80184-7

United Nations (2012) World urbanization prospects, the 2011 revision vol 2011 Revision. United Nations Department of Economic and Social Affairs Population Division, New York

USGS USGS (2015) Using the USGS Landsat 8 Product. United States Geological Survey. http://landsat.usgs.gov/Landsat8_Using_Product.php. Accessed 18 September 2015

van Den Berg AE, Custers MHG (2011) Gardening Promotes Neuroendocrine and Affective Restoration from Stress Journal of health psychology 16:3-11 doi:10.1177/1359105310365577

van den Berg AE, Jorgensen A, Wilson ER (2014) Evaluating restoration in urban green spaces: does setting type make a difference? Landscape and Urban Planning 127:173-181 doi:10.1016/j.landurbplan.2014.04.012

WHO WHO (1947) Constitution of the World Health Organisation The International Law Quarterly 1:263-280

WHO WHO (2010) Hidden cities: unmasking and overcoming health inequities in urban settings. vol Book, Whole. World Health Organization, Kobe, Japan

Yancura LA, Aldwin CM (2008) Coping and health in older adults Current Psychiatry Reports 10:10-15 doi:10.1007/s11920-008-0004-7 


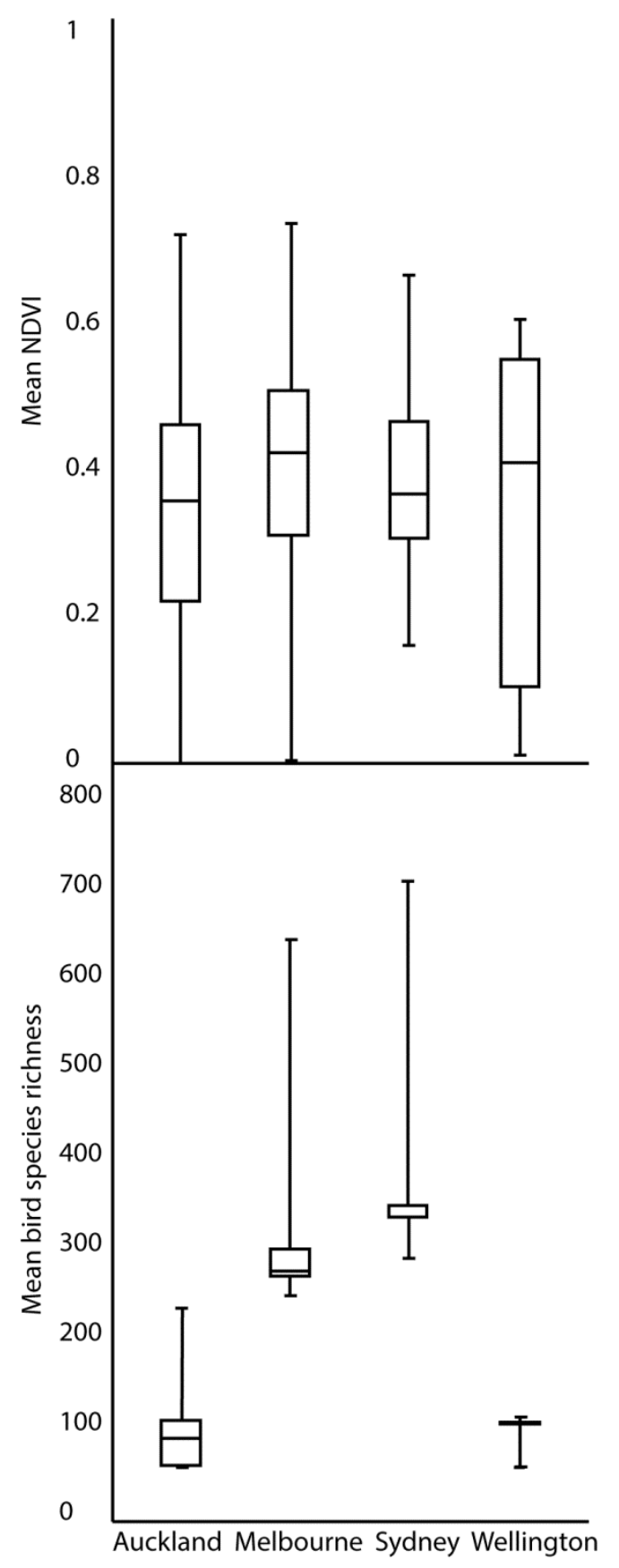




\section{Online Resource 1. A comparison of the four study cities}

The study cities represent the two most -populous cities of Australia (Melbourne and Sydney) and New Zealand (Auckland and Wellington) (ABS 2013; Statistics New Zealand 2006), yet they differ in scale, population, and biodiversity from each other.

\begin{tabular}{|c|c|c|c|c|c|c|c|c|}
\hline & Population & $\begin{array}{r}\text { Physical } \\
\text { extent } \\
\left(\mathrm{Km}^{2}\right)\end{array}$ & $\begin{array}{r}\text { n. } \\
\text { postcodes }\end{array}$ & $\begin{array}{r}\text { Average } \\
\text { responses } \\
\text { per } \\
\text { postcode }\end{array}$ & $\begin{array}{l}\text { NDVI } \\
\text { range }\end{array}$ & $\begin{array}{r}\text { NDVI } \\
\text { min-max }\end{array}$ & $\begin{array}{r}\text { Bird } \\
\text { species } \\
\text { range }\end{array}$ & $\begin{array}{r}\text { Bird species } \\
\text { min-max }\end{array}$ \\
\hline Auckland & 1303068 & 1092.64 & 140 & 2.74 & 0.69 & $\begin{array}{r}-0.003- \\
0.689\end{array}$ & 166.75 & $65.25-232$ \\
\hline Wellington & 448956 & 289.92 & 48 & 4.47 & 0.57 & $\begin{array}{r}0.007- \\
0.573\end{array}$ & 52.21 & $64.22-116.43$ \\
\hline Melbourne & 4246345 & 6571.84 & 384 & 3.47 & 0.29 & $\begin{array}{r}0.001- \\
0.294\end{array}$ & 374.14 & $245.86-620$ \\
\hline Sydney & 4667283 & 4502.3 & 400 & 4.60 & 0.12 & $\begin{array}{r}0.151- \\
0.269\end{array}$ & 397.89 & 284.11-682 \\
\hline
\end{tabular}




\section{Online Resource 2. Advertising}

The advertising and postcards used a version of the first sentence from the media release, "If you live in Sydney of Melbourne in Australia, or Auckland or Wellington in New Zealand, the University of Sydney wants to know how you interact with nature, and whether you think your wellbeing depends on nature being part of your daily life.”
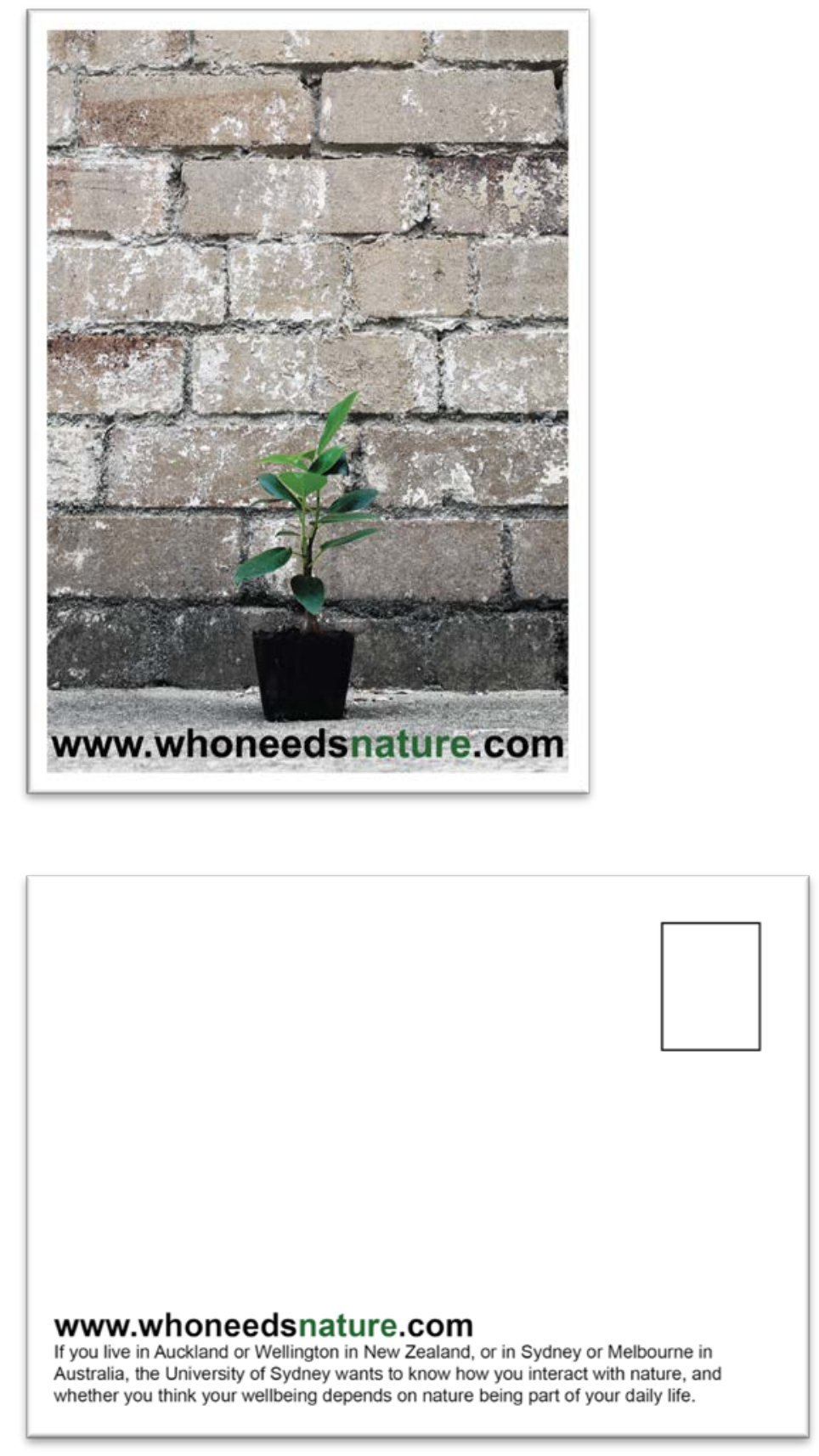


\section{Online Resource 3. Principal components}

We used principle components of each wellbeing item to create general wellbeing (WHO-5), personal wellbeing, and psychological wellbeing indices. The first principle component for each index loaded positively with all questions. The second principle components all explained less than 1 standardized unit of variance.

\begin{tabular}{|c|c|c|c|}
\hline $\begin{array}{l}\text { PCA } \\
\text { component }\end{array}$ & $\begin{array}{r}\text { PC1 } \\
\% \text { Variance } \\
\end{array}$ & $\begin{array}{r}\text { PC2 } \\
\text { \% Variance } \\
\end{array}$ & Association with variables \\
\hline Psychological wellbeing & $60.7 \%$ & $12.5 \%$ & \\
\hline \multirow{7}{*}{$\begin{array}{l}\text { The reflection axis of } \\
\text { Psychological wellbeing } \\
\text { Cronbach alpha }=0.89\end{array}$} & 0.40 & 0.02 & I feel peaceful when I go there \\
\hline & 0.41 & -0.17 & I gain perspective on life when I go there \\
\hline & 0.42 & -0.07 & Being there clears my head \\
\hline & 0.41 & -0.08 & Being there makes me feel more connected to nature \\
\hline & 0.37 & -0.06 & I can easily think about personal matters when I go there \\
\hline & 0.39 & -0.12 & $\begin{array}{l}\text { When I am there I feel part of something that is greater than } \\
\text { myself }\end{array}$ \\
\hline & 0.20 & 0.97 & I do not feel calm when I am there (Reverse scored) \\
\hline General wellbeing (WHO-5) & $72.1 \%$ & $9.3 \%$ & \\
\hline \multirow{5}{*}{$\begin{array}{l}\text { WHO-5 Wellbeing Index } \\
\text { Cronbach alpha }=0.90\end{array}$} & 0.47 & -0.20 & I have felt cheerful and in good spirits \\
\hline & 0.46 & -0.41 & I have felt calm and relaxed \\
\hline & 0.46 & -0.14 & I have felt active and vigorous \\
\hline & 0.44 & -0.04 & I woke up feeling fresh and rested \\
\hline & 0.42 & 0.88 & My daily life has been filled with things that interest me \\
\hline Personal wellbeing & $50.7 \%$ & $10.4 \%$ & \\
\hline \multirow{8}{*}{$\begin{array}{l}\text { Based on the Personal Wellbeing } \\
\text { Index } \\
\text { Cronbach alpha }=0.86\end{array}$} & 0.38 & -0.06 & I am satisfied with my standard of living \\
\hline & 0.32 & -0.08 & I am satisfied with my physical health \\
\hline & 0.31 & 0.53 & Generally, I feel safe \\
\hline & 0.30 & 0.57 & I feel like part of my community \\
\hline & 0.36 & 0.23 & I am satisfied with my future security \\
\hline & 0.38 & -0.22 & I am satisfied with my emotional wellbeing \\
\hline & 0.41 & -0.34 & I am satisfied with my life as a whole \\
\hline & 0.36 & -0.41 & I am satisfied with what I achieve in life \\
\hline
\end{tabular}




\section{Online Resource 4. Wellbeing indices and demographic variables}

We ran a general linear model looking at the way different demographic variables affected the wellbeing indices. Significant relationships are bolded.

\begin{tabular}{|c|c|c|c|c|}
\hline Personal wellbeing index & Estimate & Std Error & t Ratio & Prob $>|t|$ \\
\hline Gender & 0.171 & 0.077 & 2.22 & 0.027 \\
\hline 18-24 age group & 0.360 & 0.318 & 1.13 & 0.258 \\
\hline 25-34 age group & 0.054 & 0.209 & 0.26 & 0.798 \\
\hline $35-44$ age group & -0.183 & 0.211 & -0.87 & 0.386 \\
\hline 45-54 age group & 0.640 & 0.246 & 2.60 & 0.010 \\
\hline 55-64 age group & 0.319 & 0.297 & 1.07 & 0.283 \\
\hline $65+$ age group & -0.146 & 0.692 & -0.21 & 0.833 \\
\hline Marital status & -0.796 & 0.161 & -4.94 & $<\mathbf{0 . 0 0 1}$ \\
\hline Household with children & 0.033 & 0.077 & 0.43 & 0.664 \\
\hline Household with pets & -0.029 & 0.015 & -1.94 & 0.053 \\
\hline Years at residence & 0.046 & 0.050 & 0.93 & 0.354 \\
\hline Bedrooms at residence & 0.016 & 0.010 & 1.58 & 0.114 \\
\hline Level of education (11 years or less of primary/secondary) & 0.387 & 0.521 & 0.74 & 0.457 \\
\hline Level of education (completed highschool) & -0.318 & 0.345 & -0.92 & 0.357 \\
\hline Level of education (certificate/diploma) & 0.675 & 0.224 & 3.01 & 0.003 \\
\hline Level of education (bachelor degree) & -0.161 & 0.227 & -0.71 & 0.479 \\
\hline Level of education (postgraduate degree) & 0.473 & 0.214 & 2.21 & 0.027 \\
\hline English first language & -0.162 & 0.140 & -1.16 & 0.246 \\
\hline General wellbeing (WHO-5) index & Estimate & Std Error & t Ratio & Prob $>|t|$ \\
\hline Gender & 0.018 & 0.069 & 0.26 & 0.794 \\
\hline 18-24 age group & 0.250 & 0.285 & 0.88 & 0.382 \\
\hline 25-34 age group & 0.130 & 0.188 & 0.69 & 0.491 \\
\hline $35-44$ age group & 0.094 & 0.191 & 0.49 & 0.621 \\
\hline 45-54 age group & 0.478 & 0.219 & 2.18 & 0.029 \\
\hline 55-64 age group & 0.237 & 0.265 & 0.90 & 0.371 \\
\hline $65+$ age group & 0.585 & 0.625 & 0.94 & 0.350 \\
\hline Marital status & -0.259 & 0.145 & -1.79 & 0.074 \\
\hline Household with children & -0.029 & 0.069 & -0.42 & 0.671 \\
\hline Household with pets & 0.011 & 0.014 & 0.77 & 0.440 \\
\hline Years at residence & -0.020 & 0.045 & -0.44 & 0.657 \\
\hline Bedrooms at residence & 0.002 & 0.009 & 0.24 & 0.813 \\
\hline Level of education (11 years or less of primary/secondary) & 0.509 & 0.470 & 1.08 & 0.279 \\
\hline Level of education (completed highschool) & 0.123 & 0.311 & 0.40 & 0.692 \\
\hline Level of education (certificate/diploma) & -0.091 & 0.201 & -0.45 & 0.652 \\
\hline Level of education (bachelor degree) & 0.276 & 0.205 & 1.35 & 0.178 \\
\hline Level of education (postgraduate degree) & 0.271 & 0.192 & 1.41 & 0.159 \\
\hline English first language & -0.074 & 0.126 & -0.59 & 0.558 \\
\hline Psychological wellbeing index & Estimate & Std Error & t Ratio & Prob $>|t|$ \\
\hline Gender & 0.245 & 0.073 & 3.35 & 0.001 \\
\hline 18-24 age group & 0.461 & 0.302 & 1.53 & 0.127 \\
\hline 25-34 age group & -0.304 & 0.198 & -1.53 & 0.125 \\
\hline 35-44 age group & 0.102 & 0.202 & 0.50 & 0.614 \\
\hline 45-54 age group & 0.176 & 0.233 & 0.75 & 0.452 \\
\hline 55-64 age group & -0.044 & 0.282 & -0.16 & 0.876 \\
\hline $65+$ age group & 0.034 & 0.687 & 0.05 & 0.961 \\
\hline Marital status & -0.100 & 0.153 & -0.65 & 0.515 \\
\hline Household with children & 0.130 & 0.073 & 1.77 & 0.077 \\
\hline Household with pets & -0.001 & 0.014 & -0.11 & 0.915 \\
\hline Years at residence & -0.035 & 0.048 & -0.74 & 0.459 \\
\hline Bedrooms at residence & 0.002 & 0.010 & 0.23 & 0.819 \\
\hline Level of education (11 years or less of primary/secondary) & 0.110 & 0.501 & 0.22 & 0.827 \\
\hline Level of education (completed highschool) & 0.456 & 0.330 & 1.38 & 0.168 \\
\hline Level of education (certificate/diploma) & -0.234 & 0.213 & -1.10 & 0.274 \\
\hline Level of education (bachelor degree) & 0.271 & 0.218 & 1.25 & 0.213 \\
\hline Level of education (postgraduate degree) & -0.261 & 0.205 & -1.27 & 0.204 \\
\hline English first language & -0.164 & 0.133 & -1.24 & 0.217 \\
\hline
\end{tabular}




\section{Online Resource 5. Interactions between demographics and nature indicators}

The demographic factors that had an effect on measures of wellbeing did not have a significant effect on the nature/wellbeing relationships. Significant results are bolded.

\begin{tabular}{|c|c|c|c|c|}
\hline & Auckland & Melbourne & Sydney & Wellington \\
\hline \multicolumn{5}{|l|}{ WHO-5 } \\
\hline NDVI*age & $F(5,108)=1.66, p=0.150$ & $\mathrm{~F}(6,550)=1.78, \mathrm{p}=0.100$ & $\mathrm{~F}(6,745)=0.81, \mathrm{p}=0.559$ & $F(5,52)=1.09, p=0.378$ \\
\hline Birds*age & $F(5,108)=1.74, p=0.133$ & $F(6,543)=0.33, p=0.924$ & $F(6,731)=1.56, p=0.156$ & $F(5,52)=1.11, p=0.365$ \\
\hline Nature home*age & $F(5,102)=1.96, p=0.091$ & $F(6,530)=1.96, p=0.069$ & $F(6,710)=0.71, p=0.724$ & $F(5,48)=0.57, p=0.724$ \\
\hline Nature work*age & $F(5,91)=0.94, p=0.462$ & $F(6,498)=1.04, p=0.401$ & $F(6,659)=0.56, p=0.766$ & $F(4,48)=1.02, p=0.406$ \\
\hline \multicolumn{5}{|l|}{ Personal wellbeing } \\
\hline NDVI*gender & $F(1,115)=0.94, p=0.335$ & $F(1,555)=1.09, p=0.296$ & $F(1,745)=0.26, p=0.610$ & $F(1,60)=0.14, p=0.708$ \\
\hline NDVI*marital status & $F(1,114)=1.20, p=0.275$ & $F(1,557)=1.45, p=0.230$ & $F(1,746)=0.01, p=0.909$ & $F(1,61)=6.40, p=0.014$ \\
\hline NDVI*education & $F(4,110)=3.10, p=0.019$ & $F(5,549)=0.28, p=0.922$ & $F(5,740)=1.08, p=0.368$ & $F(4,55)=0.93, p=0.452$ \\
\hline NDVI*age & $F(5,107)=1.77, p=0.126$ & $F(6,548)=0.61, p=0.726$ & $F(6,739)=1.56, p=0.155$ & $F(5,52)=1.22, p=0.312$ \\
\hline Birds*gender & $F(1,115)=4.29, p=0.041$ & $F(1,548)=8.31, p=0.004$ & $F(1,734)=0.01, p=0.911$ & $F(1,60)=0.24, p=0.624$ \\
\hline Birds *marital status & $F(1,114)=0.01, p=0.939$ & $F(1,550)=0.46, p=0.498$ & $F(1,735)=1.04, p=0.307$ & $F(1,61)=0.17, p=0.678$ \\
\hline Birds *education & $\mathrm{F}(4,110)=0.52, \mathrm{p}=0.722$ & $F(5,542)=0.48, p=0.791$ & $F(5,729)=0.29, p=0.919$ & $F(4,55)=0.32, p=0.865$ \\
\hline Birds*Age & $F(5,107)=1.75, p=0.129$ & $F(6,541)=0.71, p=0.644$ & $F(6,728)=1.17, p=0.321$ & $F(5,52)=0.85, p=0.523$ \\
\hline Nature home*gender & $F(1,110)=2.87, p=0.093$ & $F(1,535)=0.16, p=0.693$ & $F(1,711)=0.33, p=0.563$ & $F(1,56)=1.03, p=0.314$ \\
\hline Nature home*marital & $F(1,108)=0.96, p=0.328$ & $F(1,536)=0.85, p=0.357$ & $F(1,712)=1.60, p=0.206$ & $F(1,57)=0.16, p=0.689$ \\
\hline Nature home*education & $F(4,104)=0.13, p=0.972$ & $F(5,528)=0.24, p=0.947$ & $F(5,706)=0.36, p=0.878$ & $F(4,51)=0.09, p=0.985$ \\
\hline Nature home*age & $F(5,101)=0.53, p=0.751$ & $F(6,527)=0.92, p=0.483$ & $F(6,705)=0.92, p=0.483$ & $F(5,48)=1.68, p=0.157$ \\
\hline Nature work *gender & $F(1,97)=0.52, p=0.472$ & $F(1,503)=2.22, p=0.137$ & $F(1,660)=0.39, p=0.533$ & $F(1,53)=1.33, p=0.254$ \\
\hline Nature work*marital & $F(1,97)=0.53, p=0.470$ & $F(1,505)=5.44, p=0.020$ & $F(1,660)=0.00, p=0.961$ & $F(1,54)=0.09, p=0.771$ \\
\hline Nature work*education & $F(4,92)=1.45, p=0.224$ & $F(5,497)=0.23, p=0.95$ & $F(5,654)=0.89, p=0.487$ & $F(4,48)=1.33, p=0.272$ \\
\hline Nature work*age & $F(5,90)=1.42, p=0.224$ & $F(6,496)=1.16, p=0.325$ & $F(6,653)=0.85, p=0.533$ & $F(4,48)=1.17, p=0.338$ \\
\hline \multicolumn{5}{|l|}{ Psychological wellbeing } \\
\hline NDVI*gender & $F(1,112)=0.46, p=0.501$ & $F(1,549)=2.50, p=0.115$ & $F(1,736)=0.24, p=0.623$ & $F(1,58)=0.03, p=0.874$ \\
\hline Birds*gender & $F(1,112)=1.63, p=0.205$ & $F(1,543)=0.53, p=0.465$ & $F(1,722)=1.16, p=0.282$ & $F(1,58)=0.38, p=0.538$ \\
\hline Nature home*gender & $F(1,107)=2.79, p=0.098$ & $F(1,531)=1.25, p=0.264$ & $F(1,702)=0.24, p=0.626$ & $F(1,55)=0.41, p=0.524$ \\
\hline Nature work*gender & $F(1,95)=1.07, p=0.303$ & $F(1,497)=0.32, p=0.569$ & $F(1,651)=0.00, p=0.938$ & $F(1,51)=0.52, p=0.475$ \\
\hline
\end{tabular}

\section{References}

ABS (2013) 3218.0 - Regional Population Growth, Australia, 2011-12.

http://www.abs.gov.au/ausstats/abs@.nsf/latestProducts/3218.0Media\%20Release12011-12. Accessed 25 May 2013

Statistics New Zealand (2006) 2006 Census.

http://www.stats.govt.nz/Census/2006CensusHomePage. Accessed 25 May 2013 


\section{University Library}

\section{- M M N E R VA A gateway to Melbourne's research publications}

Minerva Access is the Institutional Repository of The University of Melbourne

Author/s:

Taylor, L;Hahs, AK;Hochuli, DF

Title:

Wellbeing and urban living: nurtured by nature

Date:

2018-02-01

Citation:

Taylor, L., Hahs, A. K. \& Hochuli, D. F. (2018). Wellbeing and urban living: nurtured by nature. URBAN ECOSYSTEMS, 21 (1), pp.197-208. https://doi.org/10.1007/ s11252-017-0702-1.

Persistent Link:

http://hdl.handle.net/11343/282538 